\title{
Involvement of the superoxide dismutase enzyme in the mycorrhization process
}

\author{
Justo Arines, Antonio Vilariño and José M. Palma
}

\begin{abstract}
ARINES, J., VILARIN̄o, A ${ }^{1}$. \& PALMA, J. M. ${ }^{2}$ 1994. Involvement of the superoxide dismutase enzyme in the mycorrhization process. Agricultural Science in Finland 3: 303-307. ('Instituto de Investigaciones Agrobiológicas de Galicia (CSIC), Apdo 122, 15080-Santiago de Compostela, Spain and, ${ }^{2}$ Estación Experimental del Zaidín (CSIC), Apdo 419, 18080-Granada, Spain.)
\end{abstract}

The survivability and quality of micropropagated plants can be improved through mycorrhization. We consider that mycorrhization is important in supporting plants under stress conditions. The mechanism is not fully understood, but it seems that the enzymes involved in alleviating stress are important factors. We therefore studied superoxide dismutase (SOD; EC 1.15.1.1) isozymes. Insight is provided into the generation of superoxide radicals (SORs) and the detoxification role of SOD isozymes. Examples of how the expression of this enzyme changes in symbiotic processes are also given.

Key words: activated oxygen species, arbuscular mycorrhizal fungi, isozymes, oxidative stress, pathogenesis, superoxide radical

\section{Introduction}

Arbuscular mycorrhizal fungi (AMF) are known to be able to colonize the roots of most vascular plants and, under natural conditions, to provide a partnership with a complex system of extraradical hyphae. This extraradical system contributes to the uptake of water and nutrients and creates a modified rhizosphere favourable for plant protection in stress situations (SYLVIA and WILLIAMS 1992).

This is appreciated by mycorrhizologists, but not by all plant growers, who still do not realize that when cuttings are introduced into the soil the rooted plants become mycorrhizal, and their establishment and growth in the field are thus improved.

The technique of 'in-vitro' micropropagation is of special interest in plant propagation. Exper- iments made using this technique have shown that inoculation of recently rooted plants at the weaning stage improves the survival of the plants because they are much better able to withstand stress in a changing habitat. Growth differences between mycorrhizal and non-mycorrhizal Prunus cerasifera are very large (FORTUNA et al. 1992), confirming the importance of mycorrhiza inoculation of micropropagated plants. Mycorrhiza appears to play a key role in improving the 'exvitro' development of micropropagated Avocado plants (AzCON-AGUILAR et al. 1992) and the survival of micropropagated Anthyllis cytisoides (SAlamanca et al. 1992). Mioreover, the acclimatization phase has been reduced to eight weeks following mycorrhization with Anthyllis (SALAMANCA et al. 1992). As there is some degree of specificity in the mycorrhization of micropropagated pineapple plants (Guillemin et al. 1992), 
the growth effects are not always comparable because conditions for establishing the symbiotic change within plant and fungus species vary. This is probably a consequence of intrinsic factors and should be further investigated. The involvement of various enzymes was recently reviewed by GianinazZI (1991).

Enzymes participating in detoxification of superoxide radicals (SORs) are important during stress situations (TSANG et al. 1991). We, therefore, consider it necessary to study the extent of superoxide dismutase (SOD) involvement in the mycorrhization process.

\section{Overview of stress-causing oxygen derivatives}

Although oxygen is an essential element for life, its presence in living organisms implies that some metabolic by-products can also be formed in the cellular niche. In the presence of an adequate electron donor and slight energy activation, the reactive form of the SOR $\left(\mathrm{O}_{2}{ }^{-}\right)$is produced. Thereafter, and under acidic conditions, the presence of electron donors leads to generation of the peroxide anion, the hydroxyl radical and, finally, water (ELSTNER 1987). All these oxygen-activated forms can be detoxified by different compounds usually present in the cell, the mechanisms chosen being dependent on the particular situation and cellular location.

Biologically, the most dangerous by-product is the hydroxyl radical because of its high reactivity with chemical bonds, which causes oxidation and cleavage of the unsaturated bonds in membrane lipids termed lipid peroxidation. Hydroxyl radicals are formed in living beings by a metalcatalized Haber-Weiss reaction, where $\mathrm{H}_{2} \mathrm{O}_{2}$ and $\mathrm{O}_{2}^{-}$are precursors. Furthermore, the production of $\mathrm{H}_{2} \mathrm{O}_{2}$ is also partially dependent on either an enzyme-dependent or an enzyme-independent dismutation of the SOR. The oxidative stress generated by these radicals within the cell can be counteracted by both enzymatic and non-enzymatic mechanisms.

\section{Superoxide radicals and their dismutation}

Superoxide radicals are biologically generated during both mitochondrial respiration and photosynthesis. The steady-state level of SORs in intact mitochondria, where SOD is present, is estimated to be about $10^{-11}$ to $10^{-12} \mathrm{M}$. In washed mitochondria from which SODs are removed, SORs are estimated to account for about $4 \%$ of total oxygen. These radicals are usually generated in mitochondria, chloroplasts, the microsomal fraction, nuclei (HASSAN and SCANDALIOS 1990) and peroxisomes (DEL Rio et al. 1992).

Almost all aerobic living organisms are protected against the damaging action of SORs by superoxide dismutases, metalloenzymes which catalyze the conversion of $\mathrm{O}_{2}^{-}$to $\mathrm{H}_{2} \mathrm{O}_{2}$ and $\mathrm{O}_{2}$, $\mathrm{H}_{2} \mathrm{O}_{2}$ being then metabolized by catalase and/or peroxidases. Three types of SOD have been characterized on the basis of the metal accompanying the protein: CuZn-SOD, Mn-SOD and Fe-SOD. $\mathrm{CuZn-SOD}$ is the most abundant in eukaryotic organisms and is mainly located in the cytosol and in chloroplasts, whereas Mn-SOD is usually located in mitochondria and in peroxisomes. FeSOD was initially found in prokaryotes, but has recently been detected in chloroplasts and in plant peroxisomes. There is little difference between organisms with regard to CuZn-SODs, and their amino acid sequences show a high degree of similarity (homodimer with $32 \mathrm{kDa}$ MW). Mn-SODs are mainly tetrameric with $75-95 \mathrm{kDa} \mathrm{MW}$ in most organisms, and are phyllogenetically related to Fe-SODs.

\section{Role of superoxide dismutases in symbiotic systems}

In addition to their normal activity in plants, SODs are also associated with stress situations. The regulation of SODs in plants exposed to environmental stress has been studied by TSANG et al. (1991) by determining the presence of mRNA coding for different SODs in Nicotiana under different stress conditions (light, temperature, Para- 
quat). Their conclusion was that oxidative stress was a component of environmental stress. They demonstrated that with exposure to Paraquat, the chloroplastic Fe-SOD mRNA increased and that it was not a general reflection of other photosynthetic components. This finding suggests that the Fe-SOD gene expression is controlled by the oxidative stress itself, and is not part of a global response. Further, in mitochondrial Mn-SOD and cytosolic CuZn-SOD, the abundance of mRNA is also increased. Therefore, it is likely that, although SORs are generated within a specific compartment, the damage can affect other compartments of the cell. Of particular interest was the finding that under illuminated conditions spraying leaves with $5 \times 10^{-5} \mathrm{M}$ Paraquat increased the quantity of Fe-SODchl, Mn-SODmit and CuZnSODcyt mRNAs about 40, 30 and 15-fold, respectively. Light itself caused an increase in SODs because SORs are generated primarily by the leakage of electrons from photosystem I and from ferredoxin.

An interesting study has recently suggested that, in pathogenic situations, the expression of inducible SODs is related to resistance or susceptibility to rust in coffee plants (DAZA et al. 1993). Coffee leaves resistant to infection by the rust Hemileia vastatrix show a different SOD pattern, with two extra CuZn-SODs. This hypothesis is supported by the fact that two different coffee plant cultivars, which are resistant to infection by Hemileia vastatrix, share the same SOD pattern. A different strategy is adopted by some Phaseolus vulgaris cultivars, which are resistant to Uromyces phaseoli (BUONARIO et al. 1987). An increase in SOD activity has been detected in susceptible and resistant plants, with selective stimulation of SOD activity taking place: the manganese-enzyme in the susceptible cultivar and the cuprozinc-enzyme in the hypersensitive cultivars. Thus an increase in the Mn enzyme seems to be more closely related to the biotrophic phase of parasitism in the host cell, but an increase in the $\mathrm{CuZn}$ enzyme to the necrotic process associated with hypersensitivity (BUONARIO et al. 1987).

The first reference to SODs in symbiotic systems was by BECANA et al. (1989) in their study of free-living bacteria, bacteroids and nodules of different legumes with Rhizobium or Bradyrhizobium. Different patterns were found in each case. With Rhizobium, the transformation into bacteroids induced the expression of a new Mn-SOD.

In our laboratory we recently studied the Trifolium pratense-Glomus mosseae system (PALMA et al. 1993). G. mosseae spores contained only one CuZn-SOD (G.m. CuZn-SOD); the non-mycorrhizal root had one Mn-SOD (Mn-SOD I) and two CuZn-SODs (CuZn-SOD I and CuZn-SOD II). However, the mycorrhizal root had six SOD isozymes; besides the plant SODs indicated above, another Mn-SOD (Mn-SOD II) and two new CuZn-SODs (G.m. CuZn-SOD and mycCuZnSOD) were detected. We propose that mycCuZnSOD and Mn-SOD II were induced by the symbiosis, although we could not determine the origin of these SODs. Furthermore, the activity of CuZn-SOD I, which appeared in both kinds of root, was strongly increased after mycorrhization. Five isozymes were also detected in nodules of red clover: the three plant SODs plus two new Mn-SODs (nodMn-SOD and Mn-SOD II). nodMn-SOD was exclusively expressed in nodules, whereas nodule Mn-SOD II behaved like the MnSOD II found in mycorrhizal roots, and we postulate that it may be a uniform response of the plant to colonization by a foreign organism. We think that in red clover, both symbioses induced the expression of new SOD isozymes, suggesting that activated oxygen species must be implicated in the symbiosis. This was not the case for the Pisum sativum-Glomus mosseae symbiosis. No new isozymes were detected in mycorrhizal roots, but total activity was higher, the extra activity being accounted for by a CuZn-SOD (ARINES et al. 1994). Thus the symbiosis implies higher activity in SODs, as do other stress situations, perhaps because of the higher cellular activity associated with this process.

Results obtained by BuONARIO et al. (1987) and DAZA et al. (1993) show that various strategies may be adopted in the interaction between pathogens and plants. In mycorrhizal symbiosis, we have found that new isozymes are expressed in T. pratense-G. mosseae but not in P. sativum- 
G. mosseae. The difference may be related to the different efficiency of the symbiosis in the two plants: a higher efficiency in the colonization percentage was obtained with red clover, suggesting that the expression of new isozymes may allow the plant to cope with the excess SORs generated during the entrance of a foreign organism. However, in peas, in which a lower percentage colo- nization was determined, the plants' own SOD activity may be sufficient without inducing new isozymes. We consider that the activity of SODs is affected directly or indirectly by mycorrhization, although, as happens in plant-pathogen relationships, different strategies may be followed. Further research is needed to understand the importance of SOD in mycorrhization.

\section{References}

Arines, J., Quintela, M., Vilariño, A. \& Palma, J. M. 1994. Protein patterns and superoxide dismutase activity in non-mycorrhizal and arbuscular mycorrhizal Pisum sativum L. plants. Plant and Soil (in press).

Azcon-Aguilar, C., Barceló, A., Vidal, M. T. \& de la VINA, G. 1992. Further studies on the influence of mycorrhizas on growth and development of micropropagated avocado plants. Agronomie 12: 837-840.

Becana, M., Paris, F.J., SAndalio, L.M. \& del Río, L.A. 1989. Isoenzymes of superoxide dismutase in nodules of Phaseolus vulgaris L., Pisum sativum L., and Vigna unguiculata (L.) Walp. Plant Physiololy 90: 1286-1292.

Buonario, R., della Torre, G. \& Montalbini, P. 1987. Soluble superoxide dismutase (SOD) in susceptible and resistant host-parasite complexes of Phaseolus vulgaris and Uromyces phaseoli. Physiological and Molecular Plant Pathology 31: 173-184.

Daza, M.C., Sandalio, L.M., Quijano-Rico, M. \& del Río, L.A. 1993. Isoenzyme pattern of superoxide dismutase in coffee leaves from cultivars susceptible and resistant to the rust Hemileia vastatrix. Journal of Plant Physiology 141: 521-526.

Del Río, L. A., Sandalio, L. M., Palma, J. M., Bueno, P. \& CoRpas, F. J. 1992. Metabolism of oxygen radicals in peroxisomes and cellular implications. Free Radicals in Biology and Medicine 13: 557-580.

ELSTNER, E.F. 1987. Metabolism of activated oxygen species. In: Stumpf, P.K. \& Conn, E.E. (eds.). The Biochemistry of Plants: A comprehensive treatise, Vol. 11, Academic Press, London. p. 253-315.

Fortuna, P., Citernesi, S., Morini, S., Giovannetti, M. \& LORETI, F. 1992. Infectivity and effectiveness of different species of arbuscular mycorrhizal fungi in micropropagated plants of $\mathrm{MrS} 2 / 5$ plum rootstock. Agronomie 12: 825-829.

GianinazZı, S. 1991. Vesicular-arbuscular (endo-) mycorrhizas: cellular, biochemical and genetic aspects. Agriculture, Ecosystems and Environment 35: 105-119.

Guillemin, J.P., GianinazZi, S. \& Trouvelot, A. 1992. Screening of arbuscular endomycorrhizal fungi for establishment of micropropagated pineapple plants. Agronomie 12: 831-836.

Hassan, H.M. \& Scandalios, J.G. 1990. Superoxide dismutases in aerobic organisms. In: Stress Responses in Plants: Adaptation and Acclimation Mechanisms, Wiley-Liss, Inc. p. 175-199.

Palma, J.M., Longa, M.A., del Río, L.A. \& Arines, J. 1993. Superoxide dismutase in vesicular arbuscularmycorrhizal red clover plants. Physiologia Plantarum 87:77-83.

Salamanca, C.P., Herrera, M.A. \& Barea, J.M. 1992. Mycorrhizal inoculation of micropropagated woody legumes used in revegetation programmes for desertified Mediterranean ecosystems. Agronomie 12: 869-872.

SYlviA, D. \& Williams, S.E. 1992. Vesicular-arbuscular mycorrhizae and environmental stress. In: Bethlenfalvay, G.J. \& Linderman, R.G. (eds.). Mycorrhizae in Sustainable Agriculture. ASA Special Publication No. 54, Madison. p. 101-124.

Tsang, W.T., Bowler, C., Herouart, D., Van Camp, W., Villarroel, R., Gentello, C., Van Montagu, M. \& InZÉ, D. 1991. Differential regulation of superoxide dismutases in plants exposed to environmental stress. The Plant Cell 3: 783-792.

Manuscript received January 1994 


\title{
SELOSTUS
}

\section{Superoksidi-dismutaasientsyymin merkitys mykorritsan muodostuksessa}

\author{
Justo Arines', Antonio Vilariño' ja José M. Palma² \\ ' Instituto de Investigaciones Agrobiológicas de Galicia (CSIC), Espanja ja ${ }^{2}$ Estación Experimental \\ del Zaidin (CSIC), Espanja
}

Mykorritsan avulla voidaan lisätä mikrolisättyjen kasvien eloonjäämistä ja parantaa kasvien laatua. Tiedetään, että mykorritsa auttaa merkittävästi kasveja vaikeissa olosuhteissa. Tămän ilmiön mekanismia ei täysin tunneta, mutta kasvien stressiä lievittävillä entsyymeillä näyttää olevan siinä tärkeä merkitys. Tästä syystä tutkimme superoksidi- dismutaasientsyymejä (SOD; EC 1.15.1.1). Superoksidiradikaalien (SOR) syntymistä ja SOD-isotsyymien merkitystä detoksifikaatiossa selvitettiin myös yksityiskohtaisesti. Myös esimerkkejä näiden entsyymien ilmenemisen muuttumisesta symbioottisissa tapahtumissa on annettu. 